\title{
What's the economics of intensive silviculture?
}

\author{
by Dan McKenney ${ }^{1}$
}

\section{Introduction and Motivation}

The merits of intensive silviculture in Canada are being debated again. One specific example comes in the aftermath of the Land's for Life process in Ontario. This resulted in an agreement between industry, government and an environmental coalition and included an increase in the park network of 2.4 million hectares to roughly 9.5 million hectares putting additional pressure on wood supplies - hence the call for intensive silviculture (OMNR 1999a). Lautenschlager (2000) in this issue provides an overview of potential intensive silviculture options, including thinning, competition management and various harvest modifications. He also notes the importance of economic assessments of these options to help rank alternatives. Commitment \#22 of the Ontario Forest Accord also states " there will be a recognition of the costs, benefits and impacts associated with Intensive Forest Management activities" (OMNR 1999b).

Which silvicultural options offer the most promise? There are many choices and variants. Not all will be worthwhile according to economic criteria. Costs of adoption could in some cases be greater than the anticipated benefits. Some options may be worthwhile but budget constraints mean that choices will have to be made. As noted above economic analysis is often cited as a tool to help assess options (see also Freeman and Portney 1989, Brumelle et al. 1991). However, economics has also been criticized as a tool for guiding forest policy (Shepard 1925, Reed 1979, Fitzsimmons 1986, Reed and Baskerville 1989). The critics say that forest management should be exempt from economic analysis or that concern for economic efficiency is not valid for forestry - that it would "short-change future generations" (Klemperer 1976) because silviculture investments "always" fail the cost-benefit test.

My motivation for this paper is to clarify these arguments and identify why cost-benefit analysis is relevant and appropriate - it has implications on how we think about and practise "intensive silviculture" and the role of economics in analysing options. In my opinion there is often confusion about the application of economics to forest management, particularly between public and private foresters. The confusion seems to lie in the interpretation and implications of economic analysis. In this discussion I will stick to the economics of silviculture with the objective of increasing wood production the economics of multiple use forestry I will save for a later paper. Specifically my objectives are: 1) to provide a brief overview of economic efficiency and cost-benefit analysis why is it a good thing? and 2) identify the key elements and data needs for economic analysis of intensive silviculture.

\section{The Setting}

Forest economics is a broad field. However, much forest economics since the time of Martin Faustmann, the German

${ }^{1}$ Canadian Forest Service, 1219 Queen Street East, Sault Ste. Marie, Ontario P6A 5M7. E-mail: DMcKenne@nrcan.gc.ca forester credited as the father of discounted cash flow analysis, has focused on the problem of when to cut down a stand of trees - the so-called optimal rotation problem (Faustmann 1849, Pearse 1967, Samuelson 1976, Hyde and Newman 1991). The aim of this literature is to identify the rotation length that would maximize the value of wood pro-

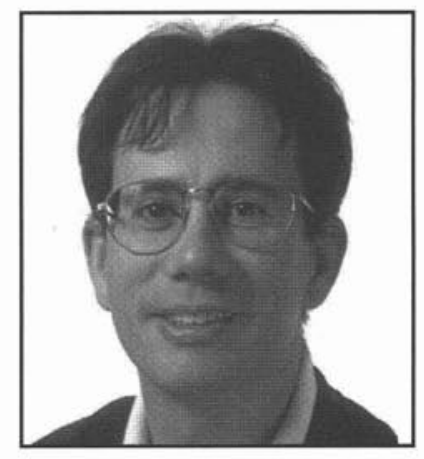
duction through time. It is this literature that provides the framework for analysing the economics of intensive silviculture. This value-maximizing objective is very different than maximizing sustainable yields from forests.

As mentioned above, the critics want to conclude that economic value calculations are irrelevant or inappropriate. The implication is they can then invoke their own criterion and will select the one that makes their favourite approach look good and pre-determines outcomes. Economists generally want to confront this approach. Dr. Glenn Fox of the University of Guelph uses the following useful analogy when explaining the economics of forestry to his students. First, observe that forests produce many things that are of value - wood, recreation, habitat and even sequester carbon. Forest management decisions require us to choose among different combinations of these valuable services. How can we do this? After considering things like "preserve habitat at all costs," "promote employment at all costs" and "maximize annual biomass production," economists suggest using money prices or estimates of money prices as an aggregator, to convert values to a common denominator. This may not be ideal, but it is really the only game in town, if we want to take all values into account and to allow trade-offs to be considered.

Second, observe that silviculture takes time. Whatever values it produces are separated through time (i.e., intertemporally separated). How can we compare values, both gains and sacrifices, that occur at different points in time? One way would be to just add up the money prices (or their surrogates) of all of the benefits and costs, regardless of when they occur. This clearly makes a very strong assumption that time preferences do not matter. In fact, we all seem to show some type of time preference (e.g., beer now is better than beer later). So if we all seem to show some degree of time preference, the practical question is really how do we reach a consensus on what rate of time preference should be applied to manage the things that we own in common? In most cost-benefit studies a range of time preference rates are used.

Usually the most contentious issue with respect to time preference is "What about future generations?" In fact, there is a relationship among current asset values, future returns and the discount rate. The simple capitalization formula, $\mathrm{V}=\mathrm{R} / \mathrm{r}$, where $\mathrm{V}$ is the value of an asset, $\mathrm{R}$ is the annual return in perpetuity and $\mathrm{r}$ is the rate of time preference, illustrates that future generations do get a partial vote in today's asset market. Part 
of $\mathrm{V}$ is the value of returns that will not be realized until everyone alive today is dead. The argument that mainstream economists put forth is that net present values of monetary measures of costs and benefits are necessary and appropriate for the evaluation of any forestry investment including intensive silviculture.

Samuelson (1976), a Nobel prize-winning economist, provides an excellent summary of the correct analysis required for optimal rotation calculations where wood production is the primary objective. He reviews a number of the mistakes that have been made by foresters (and economists) when they attempted to solve the optimal rotation problem. Incorrect approaches include maximising the internal rate of return and maximizing wood flows over time. These methods essentially ignore various "opportunity costs" involved with wood production, particularly the time value of monetary investments, and land costs. Opportunity costs are a key concept in economic analyses - they represent costs associated with potential lost opportunities (e.g., investments elsewhere in the economy). The correct calculation of an optimal rotation length determines the period that maximises the net discounted value of wood production, excluding land rent but calculated over an infinite number of rotation periods. Another approach maximises the net present value over the first rotation period but includes land rent in the calculation (Samuelson 1976). Land rent in this context represents the opportunity cost of the land in its highest valued alternative use - what we give up by designating a particular land use. Complete articulations of the mathematics of the problem are found in Hyde (1981), Bowes and Krutilla (1989), and Johansson and Lofgren (1985).

\section{A Brief Overview of Economic Efficiency and Cost-Benefit Analysis}

Whether done explicitly or not, natural resource planning involves decisions about investment, extraction and asset management. Economic theory shows that given certain conditions market clearing equilibria represent "efficient" allocations (Bohm 1987). The important conditions include the absence of external effects and public goods, a "sufficient" degree of information about prices and competition existing among many producers who are profit maximisers and consumers who are utility maximisers (all individual agents will therefore act as price takers). Utility maximization is a somewhat mystical but necessary abstraction used by economists - it has been called a "metaphysical concept of impregnable circularity" (Robinson 1962). It represents the satisfaction that individuals receive from consuming goods and services. The fact that people want them shows they do have utility. Consumers make choices based on their own views of what satisfies them and their budget constraints.

Clearly, producers and consumers are faced with current decisions that affect their well-being through time. Producers utilize current resources or borrow money at the market rate of interest to produce goods through time such that their rate of return on marginal investments equals the market rate of interest. Similarly, consumers can save or borrow at the market rate of interest. It follows then that as long as producers are profit maximisers and consumers are utility maximisers intertemporal efficiency will result. All assets will be earning an equal rate of return. No reallocation of the total economy's investments could increase that return. When rates of return do dif- fer between assets, market incentives will result in a reallocation of investments that will eventually equalise returns.

So, given certain assumptions, forestry enterprises maximising the value of their assets would serve this particular notion of the public interest - intertemporal efficiency. Pursuit of intertemporal efficiency is seen as a good thing because it represents a recognition of consumer preferences, often referred to as consumer sovereignty, and financial and technological realities facing producers. The intersection of demand and supply through time reflects a balance between wants and needs and the scarcity of all factors of production. Market prices provide signals to both producers and consumers about relative scarcity and implicitly provide incentives for conservation (or waste!).

The above discussion is about capital theory. The relevance of much of natural resource economics theory cannot be appreciated without a basic understanding of the notion of efficiency. Chapters 6 and 7 of Common (1988) cover the main ideas and applications to natural resources in an introductory non-mathematical way. Bohm (1987) gives a concise treatment of efficiency in perfect and imperfect market conditions and a useful review of the principles of cost-benefit analysis $^{2}$.

Capital theory would say the solution to the problem is that the stand should be harvested when the rate of change in its value, that is its discounted net value, equals the interest on its value plus the interest on the value of the forest land. Or put another way, a stand should be left uncut until the rate of growth of the asset (i.e., the wood and the land), equals the interest or time preference rate. This is equivalent to intertemporally efficient cost-benefit conditions where the interest rate represents rates of return to other investments in the economy. The choice of the "best" intensive silviculture option would be the one that has the highest net present value. This will vary according to the growth potential of the option, its cost through time and the standing timber values. If the harvest is too soon the owner is sacrificing a return than is greater than he could receive elsewhere. If the harvest is delayed past the point where the growth in the value of the stand is as great as

\footnotetext{
${ }^{2}$ Some commentators flatly reject the application of consumer sovereignty and concern about economic efficiency to environmental decision-making (e.g., Sagoff 1988). Sagoff argues that individuals act and respond differently to environmental problems as consumers or as citizens. This argument represents an ethical perspective that challenges the relevance and validity of economics for certain types of decision-making. Economists have developed monetary valuation techniques like contingent valuation and the travel cost method to provide pseudo-prices for things that don't have values as expressed through markets. The original motivation for the development of these values is comprehensive cost-benefit analysis applied to problems like multiple-use forestry. Prices literally provide a mechanism to compare apples and oranges. However, non-market valuation requires an assumption of commensurability between ordinary commodities (e.g., wood products) and environmental commodities (e.g., biodiversity) (see Common 1995). It is fair to say non-market valuation has both theoretical and practical challenges and includes other attacks on its validity and reliability (see Smith 1992 and Vatn and Bromley 1994) for alternative views). I note these points because some readers may feel it is essential to their position on applying economics to forestry. However I would argue that ranking the viability of intensive silviculture options is, certainly in the first instance, removed from this debate and that economic analysis has a very important role to play in clarifying options and objectives. Discussion of the limits of economics is a larger more complicated issue (Common 1995).
} 
the interest rate the owner is also losing possible revenue that could be obtained by harvesting and regenerating.

Cost-benefit analysis is the tool to apply capital theory. The most general criterion for profitable and hence worthwhile investments, is that the discounted or present value of all benefits less all costs occurring through time be greater than zero. There are many texts that comprehensively review the principles and procedures of CB analysis (e.g., Dasgupta and Pearce 1972, Mishan 1977, Sassone and Schaffer 1978, Sugden and Williams 1978, Pearce and Nash 1981).

The main features of $\mathrm{CB}$ analysis are summarised below:

1. Quantification - the identification and measurement of the costs and benefits in physical terms being sure that the categories are mutually exclusive to eliminate double counting and exhaustive enough to ensure that all the relevant categories are present for the study.

2. Valuation - attaching values or prices to the physical effects of a project or projects.

3. Discounting - determining the relevant time preference or discount rate (rate of return) for the economy when evaluating time flows of cost and benefits.

4. Constraints - determining the relevant social constraints for consideration in the analysis.

5. Uncertainty - determining how to incorporate future physical and economic uncertainties into the analysis.

6. Criterion - identification of the appropriate criteria for the evaluation (eg net present value, internal rate of return, benefit-cost ratio).

\section{Key Elements for Cost-Benefit Analysis of Intensive Silviculture}

Key elements of cost-benefit analysis of intensive silviculture are: standing timber values, establishment and management costs, growth and yields, and a discount rate. Note that standing timber values are "stumpage values," not necessarily the administered stumpage price that firms pay. Intensive silviculture, which is aimed at increasing fibre (standing timber) production, could affect all of these elements.

\section{1) The value of standing timber}

This is probably the biggest source of controversy between foresters and economists. Standing timber or stumpage values result from both supply and demand forces. Demand for stumpage is derived from the demand for consumer products (e.g., timber, pulp and paper products) that it helps to produce. Final product demands are influenced by the price of the product and its substitutes, income levels and consumer tastes and attitudes. The value of stumpage to a particular firm can be influenced by a number of factors including: tree diameter, logging method employed, terrain, sometimes weather conditions, average volume per hectare harvested, haul distance and, forest regeneration method or other forest management restrictions in so far as they affect harvesting costs, (Jackson and McQuillan 1979). Citing earlier work Jackson and McQuillan (1979) suggest that stumpage value increases at a decreasing rate as a function of tree size. Per unit volume felling, bucking, skidding and loading costs decrease with increasing diameter while value at the mill increases due to lower per unit handling costs and higher (potential) end product value. For private landowners stumpage prices are an important shortrun factor affecting a landowner's decision to harvest. If the stumpage price is greater than their own reservation price and the short-run costs, i.e., administration, appraisal and perhaps road-building costs, then owners can harvest and make a short-run profit (Hyde 1984). However, the reservation price may be related to the landowner's non-wood objectives. Non-wood values aside, whether forests are managed on an economically viable basis for wood production depends on stumpage price expectations through time exceeding the costs of growing the crop.

Extraction costs and land rent vary as distance from harvesting site to a mill or market centre increases. For a given uniform land base and price, as distance from a mill increases per hectare rent declines and per hectare extraction costs increase due to transportation charges. For a given price there is a finite perimeter of economically profitable extraction (Hyde 1980). When stumpage price increases the area of commercial forest land, therefore, increases and total rent increases.

When public land is the only or major wood supplier, then stumpage price determination becomes more problematic. Public forest agencies in many countries tend to set stumpage prices through an administrative process rather than through pure market forces. Residual pricing is a common approach for valuing standing timber in such circumstances. A residual value for stumpage can be calculated by subtracting producer costs, including an allowance for normal profit, from the price received for the final product. This should theoretically determine the rent. Stumpage fees on public land sometimes attempt to capture this rent. Strictly speaking, this approach says nothing about the appropriateness of the residual value as the actual stumpage price. The residual approach implicitly accepts the existing industry structure as efficient (Byron and Douglas 1981). Nor does the residual value approach provide information about the opportunity costs of the land. Essentially, policy-makers are informed about what the stumpage price should be to maintain the current structure of the processing sector, not about what the price should be if efficiency was a goal of the forest growing component.

What does this mean for forester managers? Individual forests should grow and sell as much stumpage as possible using a notional "world price" as a guide for profitability and after consideration of transportation charges (see Johansson and Lofgren 1985, Chapter 11). This is primarily due to most open economies and, in principle, forests being price-takers. In the long run, no individual forest will influence prices. General equilibrium implications of management decisions can be evaluated using, in this instance, world market prices as shadow prices (opportunity costs). In Canada this value would be somewhere between stumpage fees and "freight on board" (FOB) delivered-to-the-mill prices of harvested logs (or chips) net of transportation and harvest costs. This value represents the willingness to pay for standing timber by firms and a maximum value that growers could expect to extract from stumpage buyers. So, despite the fact that wood and wood products are tradable, priced commodities, the determination of the appropriate stumpage value to use in cost-benefit analysis is still a challenge. Precise values are difficult to estimate, let alone forecast into the future. However, a well-constructed cost-benefit analysis can, through sensitivity analysis, help identify what stumpage values would have to be to justify particular silvicultural investments. This is important given the debate about quality versus quantity fibre production. The key point is 
there are upper limits to stumpage values that need to be recognized because wood products do have substitutes. Price trends for final products also provide insights. (Sedjo and Lyon 1990)

\section{2) Establishment and Management Costs}

While the identification of silvicultural costs may seem obvious, in practice this also is non-trivial and therefore seems worthy of some comment. There does appear to be a lack of comprehensive studies on the cost of providing natural resources. The Forest Engineering Research Institute of Canada provides information on harvest costs that can be used to help gauge differences in some harvesting alternatives. However, it is surprisingly difficult to obtain reliable cost data on growing wood, let alone the costs of providing various recreational and conservation benefits. More importantly, these costs are likely to vary spatially and even by firm. Efforts are required to better document all regeneration and management costs by site type and the variance around these costs. This may indirectly provide insights into research needs and opportunities and make it easier to estimate the cost of new intensive silviculture options.

\section{3) Estimating growth and yield changes due to intensive silviculture}

This is clearly the key area for many forest scientists. Growth responses are variable and often unknown and in some cases researchers seem reticent to make forecasts. Nevertheless, forecasts are required to evaluate the potential of different options. Most researchers can place realistic bounds on the likely response of different treatments. In fact, growth responses are often used as a rationale during the proposal-writing stage of research projects. It would be useful if economic analyses were used as an initial filtering mechanism.

\section{4) The time preference or "discount" rate}

The choice of discount rate can also profoundly affect the outcome of a cost-benefit analysis. With sufficiently high discount rates some types of silviculture and even ongoing timber management is not worthwhile and mining versus preservation becomes the economic choice. Economists insist on using discount rates to weigh the benefits and costs of activities that occur through time and bring them back to a common starting point. Foresters sometimes interpret this as saying it does not pay to grow trees (Shepard 1925, Reed 1979, Fitzsimmons 1986). The discount rate is again something that represents real opportunity costs and, hence, should be included in assessment of silviculture options. Economists would or should not flatly state that it does not pay to grow trees. They should state that it does not pay to apply a particular silvicultural technique because the likely returns are insufficient to cover the costs and then politely suggest the forester goes back to the drawing board to suggest an alternative option!

\section{Some Criticisms and Comments on the Eco- nomic Approach}

As mentioned at the outset, stand level economics has its critics. In this section I will attempt to represent some of their main points. I believe many of their criticisms are misplaced and incorrect. A good example is a paper by Reed and Baskerville (1989) in which they question the premise and rel- evance of the Faustmann-type framework. They list a number of concerns:

a) Today we begin not with an individual plot of bare clearcut on which stands might be grown, but with whole forests already in place and in which a few stands are treated annually;

b) The areas are vast and embrace a multiplicity of stand types and conditions;

c) Silviculture costs are charged against current revenues as an annual cost of staying in business;

d) Stand treatments are not independent, and indeed benefits of silviculture arise in parts of the forest other than the treated hectares, as well before the new plantation matures;

e) The timber land is part of a total provincial or corporate enterprise

f) The benefits of silviculture treatments include less time for trees to reach operable size, increased harvest volumes, lower harvesting and processing costs, higher value products, and reductions in risk;

g) Finally, very worthwhile benefits accrue in terms of non-timber values.

My response:

a) The original Faustmann model starts with bare land while Reed and Baskerville start with forests in place; however, the basic framework provided by the Faustmann model is relevant whether the stand is at the beginning, middle or near the end of its possible rotation. The problem to be assessed is what can be done to the stand to maximize its value, cognizant of the cost of these options, the likely growth response, and the expected value of the harvestable fibre through time.

b) Forests are indeed "vast" and contain a "multiplicity of stand types and conditions." This reinforces the need to be prudent and selective in applying silvicultural options. A good forester likes to apply "site- specific" prescriptions. Economists would suggest that these prescriptions be evaluated in terms of their economic worth, not just their physical yields. This task is not as daunting as may first appear. Fast computers, linear programming-based forest planning tools and spreadsheet programs are now commonplace. These tools organize data on current forest conditions and, if properly structured, can help evaluate the economic viability of silvicultural options.

c) and d) Reed and Baskerville suggest silvicultural costs be charged against current revenues and that stand treatments are not independent. While it may be possible to expense or write off silvicultural costs against current revenues (depending on tax rules), this does not disguise the fact that these expenditures still represent investments in future wood production that arise from independent, sitespecific prescriptions invoked for biological reasons. Economists would argue that the site-specific prescriptions include an assessment of the costs and benefits of the options. Reed and Baskerville also suggest there is a dependence between stand treatments so that "allowable cut effects" (ACE) can be invoked. The ACE is a complicated and controversial issue and a point of contention between foresters and economists (Hyde 1981, Tait 1987). To risk over-simplification, the allowable cut 
effect results in increases in forest-wide harvest levels arising from expected increased growth in treated stands. The implication is that particular forest stands are harvested without an explicit consideration of their own economic benefits or costs.

e) The "timber land" is part of a larger corporate or provincial asset. This is obviously true and reinforces the need for a better understanding of the use and misuse of economic analysis. The stakes are particularly high in Canada because of the size of the forest estate and the role of taxpayers in funding forest management either directly or indirectly. Maximizing wood asset values will be achieved by pursuing the goal of intertemporal efficiency as described above.

Critics argue that using stumpage prices when evaluating the costs and benefits of forest management decisions ignores the value of the final product to the economy. However, if the assumption that competitive markets exist in the processing sector is accepted, then net economic welfare changes due to forest management activities are reflected through stumpage values (Carlton 1979, Jacobsen 1979). The point is that the economic value to attribute to increased wood production due to intensive silviculture is not the final product price. Using final product prices (e.g., pulp, newsprint, $2 \times 4 \mathrm{~s}$, etc.) as the value of standing timber assumes that all of the other factors of production had no other uses. Over the long run such an assumption is obviously dubious. Using value-added final product prices to evaluate the net benefits of silviculture would likely suggest that all silviculture is worthwhile and we should be practising (intensive) silviculture on all land.

Maintenance of employment opportunities is sometimes an implicit objective of forest management. If employment in the wood processing sectors is a key objective of forest policy, this should be stated explicitly and the cost of that policy carefully enumerated and compared to the value of intertemporally efficient wood production. This would help quantify the cost of such policies to taxpayers. Intensive silviculture may not be the most effective means of achieving these types of social goals. Most economists would probably suggest that we don't cut trees down to provide jobs to loggers any more than we have schools to provide jobs for school bus drivers. Employment is a consequence of the fact that consumers value wood products, not the objective. Maximizing labour opportunities involves income transfers with costs of such a program being diffused to taxpayers. The capacity of governments to fund employment opportunities has been widely debated in recent years. Boyd and Hyde (1989) discuss these types of issues in the forest sector specifically. The aim of stand-level economic analysis is to help define and prescribe the conditions for forest management to pay for itself.

f) Reed and Baskerville say that stand level economic analysis ignores other benefits, like less time for trees to reach operable size, increased harvest volumes, lower harvesting and processing costs, higher value products, and reductions in risk. These criticisms are misplaced. Properly constructed analysis should attempt to account for these differences if they are expected to exist. They manifest themselves in terms of changing prices or price premiums relative to the status quo. They are, in fact, the exact reason why cost-benefit analysis is undertaken - to determine whether or not these benefits are worth the cost.

g) Non-wood objectives are clearly a fundamental consideration in forest management. The economics of forestry has in fact evolved to include non-market values (Hartman 1976, Bowes and Krutilla 1989, McKenney 1990). While there remain many practical and even theoretical issues to deal with (McKenney and Sarker 1994, McKenney et al. 1999), economic analysis can in the short run help quantify the cost of achieving non-wood objectives and identify the most cost-effective means of achieving these goals. In fact, the merits of intensifying management on a small proportion of the land base are being more widely debated and discussed worldwide (Taylor 1999, Spears $2000^{3}$ ). An important rationale for propositions like this is for more effective biodiversity conservation, not just increased wood production. While this certainly complicates the story for economic analysis in forest planning, the starting point is assessing the costs and benefits of alternative stand-level silvicultural practices.

\section{Mine, Preserve or Somewhere In-between?}

Two important polar cases exist as potential management alternatives for forests. Understanding the economics of these helps to clarify the boundaries of efficient silviculture. The first case is that of timber mining - treating the forest like a nonrenewable resource such that there are no intentional silvicultural investments and in the most extreme (and unlikely) case no commercially viable regrowth is expected. The second case is that of forest preservation - the non-wood attributes of the forest are considered so valuable as to disallow any harvesting in the area.

According to well-accepted economic theory, harvesting a forest and using the land for wood production is worthwhile if the discounted sum of the current value of harvesting, plus the present value of all future (Faustmann) rotations, exceeds the total willingness to pay (WTP) for preserving the forest for all time periods in the planning horizon (Johansson and Lofgren 1985). When the present value of forestry is not positive, then ongoing timber management is inefficient and the problem is reduced to timber mining or forest preservation. If ongoing timber management is inefficient and the WTP to preserve the forest does not exceed the value of extracting (mining) the current wood resources in the forest, then mining is the economically efficient management strategy. If this WTP exceeds wood values then preservation is most economically efficient.

There are a few points associated with these management choices that are critical. Consumer preferences, for both wood products (and, hence, stumpage values) and preservation, may and probably will change over time. This could affect relative values, thus changing the socially efficient outcome. Fisher and Krutilla (1985) for example, argued that wilderness is becoming increasingly scarce and is thereby increasing in relative value over time. There is, of course, no guarantee that future generations would impute similar values to wilderness,

\footnotetext{
${ }^{3}$ Spears, J. 2000. Worldbank/WWF Alliance/Council on Foreign Relations Global Vision Project. Briefing paper for the Project Steering Committee. Washington DC. Unpublished manuscript.
} 
but experience suggests this trend is continuing. This highlights the fact that economic analysis is for decisions now, based on current conditions and the expected outcomes of all technically possible choices. Conditions and knowledge may change tomorrow or next year making the optimal decision different.

Timber mining is sometimes considered to be bad land stewardship and not a valid option for public forest agencies. However, from an efficiency perspective it may be rational. In situations where mining is not considered as an option, forest preservation could, in fact, be the most efficient land use. Ongoing forest management could be so inefficient as to cause large losses or income transfers. Anderson (1979) argued this was the case for some Ontario silviculture where large investments were required for relatively slow-growing forests (see also Cartwright 1999).

Debates about the "right" value to place on standing timber can be a double-edged sword. Low stumpage values and price expectations could result in timber mining being the most appropriate economic management of the forest. Ironically, the WTP required to justify preservation is lower in this case. Higher stumpage prices increase the cost of preservation.

\section{Concluding Comments}

The important point is that an economic framework helps to identify what we have to believe for a particular option to be worthwhile. The merits of these assumptions can then be debated explicitly. One example is work on the economics of tree improvement (McKenney et al. 1989), which compared clonal forestry to conventional seed orchard tree improvement to unimproved plantations in Ontario. Even though clonal forestry had the potential to increase growth rates much more, the assumptions required to believe that it would be worthwhile were highly unlikely. Growth rates would have to be unrealistically high. Clone production costs would also have to be much less. Another example is an assessment of uneven-aged silviculture options on medium quality black spruce sites in Ontario (McKenney et al. 1997). The path of prices through time affected the viability of particular options in that case.

Intensive silviculture pays for itself in many parts of the world. Expenditures in forest management in Canada should be guided by expected returns and efficiency criterion. There are limits on expenditures beyond which it is unrealistic to expect a positive return. Benson (1988) recognized these limits in arguing for extensive forestry in Canada [see also Oliver (1999) for a discussion on the subject]. However, there are unresolved issues before blanket statements are invoked. One is forecasting stumpage values to use in economic assessments. Realistic boundaries on future standing timber values are required for all species and size and quality classes - much more easily said than done. Better estimates of growth responses and costs are also required to more rigorously assess the economics of intensive silviculture. Institutional barriers and other incentives affecting silviculture expenditures also need to be clearly understood (Pearse 1985).

I have chosen not to present specific numerical examples because of the tremendous spatial variation in growth rates and costs across the country. Like intensive silviculture, economic analysis needs to be applied on a site-specific basis. Readers can come to their own conclusions based on the analytical framework and interpretations described here.

Ralph Goodale, Canada's Minister of Natural Resources has said (Natural Resources Canada 1999):
For the next century, Canada must become the world's smartest natural resource steward, developer, user and exporter: the most high tech; the most environmentally friendly; the most socially responsible; the most competitive and productive.

With the caveat that there are always exceptions, important attributes of competitive silviculture for Canada would be relatively low costs of adoption and stand intervention strategies that occur near the end of the rotation period. The charge to forest scientists and foresters is to determine how to do this.

\section{Acknowledgements}

I would like to thank but not implicate Guy Smith, Mike Weber, R.A. Lautenschlager, Art Groot, Lisa Venier and Glenn Fox for reviewing and commenting on an earlier version of this manuscript. The usual disclaimer applies.

\section{References}

Anderson, F.J. 1979. Ontario Reforestation Policy: Benefits and Costs. Can. Public Policy, No. 5: 336-347.

Benson, C.A. 1988. A need for extensive forest management. For. Chron. 64(5): 421-430.

Bohm, P. 1987. Social efficiency: a concise introduction to welfare economics. Macmillan Press Ltd., Melbourne

Bowes, M.D., and J.V. Krutilla. 1989. Multiple-use Management: the economics of public forestlands. Resources for the Future, Washington, D.C.

Boyd, R.G. and W.F. Hyde. 1989. Forestry Sector Intervention: The Impacts of Public Regulation on Social Welfare. Iowa State University Press, Ames, Iowa. 295 p.

Brumelle, S.L., J.S. Carley, I.B. Vertinsky and D.A. Wehrung. 1991. Evaluating silvicultural investments: a review in the Canadian context. Forestry Abstracts Vol. 52, No. 9.

Byron, R.N. and J.J. Douglas. 1981. Log pricing in Australia: policies, practices and consequences. BFE Press, Canberra.

Carlton, D.W. 1979. Valuing Market Benefits and Costs in Related Output and Input Markets. American Economic Review 69: 688-696.

Cartwright, J. 1999. The price of compromise: Why we should wind down our industry. Canadian Public Policy XXV(2): 233-245.

Common, M.S. 1988. Environmental and resource economics: an introduction. Longman, London.

Common, M.S. 1995. Sustainability and Policy: Limits to Economics. Cambridge University Press, Cambridge. 348 p.

Dasgupta, A.K. and D.W Pearce. 1972. Cost-Benefit Analysis: Theory and Practice. The Macmillan Press, London.

Faustmann, M. 1849. On the Determination of the Value Which Forest Land and Immature Stands Possess for Forestry. English edition In M. Gane (ed.). 1968. Martin Faustmann and the Evolution of Discounted Cash Flow. Institute Paper 42, Commonwealth Forestry Institute, Oxford University.

Fisher, A.C. and J.V. Krutilla. 1985. Economics of nature preservation. In A.V. Kneese and J.L. Sweeney (eds.). Handbook of Natural Resource and Energy Economics Vol. I. pp.165-190. North Holland, Netherlands.

Fitzsimmons, J. 1986. Discount Rates and Forestry Decisions. New Zealand Journal of Forestry, August 1986: 22-25.

Freeman, A.M. and P.R. Portney. 1989. Economics Clarifies Choices - Benefit-cost analysis provides guidance. Journal of Forestry, November: 34-39.

Hartman, R. 1976. The Harvesting Decision When a Standing Forest Has Value. Economic Inquiry 14: 52-58.

Hyde, W. F. 1980. Timber Supply, Land Allocation and Economic Efficiency. Johns Hopkins University Press for Resources for the Future, Baltimore.

Hyde, W.F. 1981. Volume or value maximization in forestry: an 
historical rationale and a glance at emerging technologies, Annals of Regional Science 15: 55-71.

Hyde, W.F. 1984. Timber valuation. In G. Peterson and A. Randall (eds.).Valuation of Wildland Resource Benefits. Westview Press, Boulder.

Hyde, W.F. and D.H. Newman. 1991. Forest Economics and Policy Analysis: An Overview. World Bank Discussion Paper No. 134. Washington, D.C.

Jackson, D.H. and A.G. McQuillan. 1979. A technique for estimating timber value based on tree size, management variables and market conditions. Forest Science 25(4): 620-626.

Jacobsen, S.E. 1979. On the Equivalence of Input and Output Market Marshallian Surplus Measures. American Economic Review 69: 423-428.

Johansson, P. and K. Lofgren. 1985. The Economics of Forestry and Natural Resources. Basil Blackwell, Great Britain.

Klemperer, W.D. 1976. Economic Analysis Applied to Forestry: Does it short-change future generations? J. For. (9): 609-611.

Lautenschlager, R.A. 2000. Can intensive silviculture contribute to sustainable forest management in northern ecosystems? For. Chron. 76(2): 283-295.

McKenney, D.W. 1990. The Evolving Economics of Long-Term Forest Planning. PhD Thesis, The Australian National University. Canberra, Australia.

McKenney, D. W., N. Beke, G. Fox and A. Groot. 1997. Does it pay to do silviculture research on slow growing species: For. Ecology and Management 95: 141-152.

McKenney, D.W., B.G. Mackey and H. Macdonald. 1999. Biodiversity conservation and economic preferences. In S. Mahendrarajah, A.J. Jakeman and M. McAleer (eds.). Modelling Change in Integrated Economic and Environmental Systems. pp. 215-239. John Wiley and Sons, Ltd.

McKenney, D.W. and R. Sarker. 1994. An overview of nonwood valuation efforts in Ontario, For. Chron. 70(1): 47-54.

McKenney, D.W., W. van Vuuren and G. Fox. 1989. An economic comparison of alternative tree improvement strategies: assimilation approach. Canadian J. Agricultural Economics 37: 211-232.

Mishan, E.J. 1977. Cost-Benefit Analysis, George Allen and Unwin, Ltd, London

Natural Resources Canada. 1999. The State of Canada's Forests. Canadian Forest Service, Ottawa. 112 p.

Oliver, C.D. 1999. The future of the forest management industry: Highly mechanized plantations and reserves or a knowledge-intensive integrated approach? For. Chron. 75(2): 229-245.
Ontario Ministry of Natural Resources (OMNR). 1999a. Ontario's Living Legacy Land Use Strategy. Queen's Printer for Ontario, Toronto, ON. 136 p.

Ontario Ministry of Natural Resources (OMNR). 1999b. Ontario Forest Accord - A foundation for progress. Queen's Printer for Ontario, Toronto, ON. 136 p.

Pearce, D.W. and C.A. Nash. 1981. The Social Appraisal of Projects: A text in Cost-Benefit Analysis. The Macmillan Press, Ltd, London.

Pearse, P.H. 1967. The Optimum Forest Rotation. For. Chron. 43: 178-195.

Pearse, P.H. 1985. Obstacles to Silviculture in Canada. For. Chron. 61(2): 91-96.

Reed, F.L.C. 1979. Realizing the Economic Potential of Canada's Forest Resource. For. Chron. 55(6): 217-221.

Reed, F.L.C. and G.L. Baskerville. 1989. Policy Forum: A Contemporary Perspective on Silviculture Investments. Journal of Business Administration Vol. 19 No. 1\&2.

Robinson, J. 1962. Economic Philosophy. Penguin Books Ltd., Middlesex, England.

Sagoff, M. 1988. The economy of the earth. Cambridge University Press, Melborne.

Samuelson, P.A. 1976. Economics of Forestry in an Evolving Society, Economic Inquiry 14: 466-492.

Sassone, P.G. and W.A. Schaffer. 1978. Cost-Benefit Analysis (Academic Press).

Sedjo, R.A. and K.S. Lyon. 1990. The Long-term Adequacy of World Timber Supply. Resources for the Future, Washington, DC.

Shepard, W. 1925. The bogey of compound interest. J. For. 23: 251-259.

Smith, V.K. 1992. Arbitrary values, good causes, and premature verdicts. Journal of Environmental Economics and Management 22: 71-87. Sugden, R. and A. Williams. 1978. The Principles of Practical CostBenefit Analysis. Oxford University Press.

Tait, D.E.N. 1987. The good fairy problem: one more look at the optimum rotation age for a forest stand. For. Chron. 63(4): 260-263.

Taylor, N.W. (Chair). 1999. Competing realities: The boreal forest at risk. Report of the sub-committee on boreal forest of the standing Senate committee on agriculture and forestry. Ottawa, ON.

Vatn A. and D.W. Bromeley 1994. Choices without prices without apologies. Journal of Environmental Economics and Management 26: $129-148$. 